\title{
Seismic Hazard Analysis Study of New Semarang International Airport Due to Shallow Crustal Fault Earthquake Scenario
}

\author{
Windu Partono, Masyhur Irsyam, I. Wayan Sengara, Asrurifak, \\ Frida Kistiani, Undayani Cita Sari and Haryadi
}

\begin{abstract}
Ahmad Yani International Airport is located in Semarang (the Capital City of Central Java Province) Indonesia. The airport was first operated on June 6 2018 and designed it using 2012 Indonesian Seismic Code (SNI 1726:2012 in Seismic resistance design codes for building and other structures, Jakarta, pp 1-138, [16]). The airport was commercially operated one year after the new Indonesian Seismic Hazard Maps 2017 released (ISHM-2017). The most important information obtained from ISHM-2017 is the new predicted seismic source located close to the airport area. This paper expresses the seismic hazard analysis (SHA) of the airport area based on the new ISHM-2017. The analysis is performed by conducting three basic SHA steps such as the Probabilistic and Deterministic Seismic Hazard Analysis (PSHA and DSHA), a combination of PSHA and DSHA for developing Most Considered Earthquake Risk $\left(\mathrm{MCE}_{\mathrm{R}}\right)$ spectral acceleration and the final analysis is related with the calculation of surface spectral acceleration for developing design spectral acceleration (DSA). The new DSA is then compared to the previous DSA developed based on SNI 1726:2012 (SNI 1726:2012 in Seismic resistance design codes for building and other structures, Jakarta, pp 1-138, [16]) and also compared to the surface spectral acceleration developed using site response analysis (SRA). The result of the study shows that the new DSA has no significant differences and improvements compared to the previous DSA (SNI 1726:2012 in Seismic resistance design codes for building and other structures, Jakarta, pp 1-138, [16]) and SRA results.
\end{abstract}

\footnotetext{
W. Partono (凹) · F. Kistiani · U. C. Sari · Haryadi

Civil Engineering Department, Engineering Faculty, Diponegoro University,

Semarang 50275, Indonesia

e-mail: windu_bapake_dila@yahoo.com

M. Irsyam · I. W. Sengara

Civil Engineering Department, Faculty of Civil and Environmental Engineering,

Bandung Institute of Technology, Bandung 40132, Indonesia

Asrurifak

Research Center for Disaster Mitigation, Bandung Institute of Technology,

Bandung 40132, Indonesia

(C) Springer Nature Switzerland AG 2020

F. Mohamed Nazri (ed.), Proceedings of AICCE'19, Lecture Notes in Civil

Engineering 53, https://doi.org/10.1007/978-3-030-32816-0_15
} 
Keywords $\mathrm{PSHA} \cdot \mathrm{DSHA} \cdot \mathrm{SRA} \cdot \mathrm{MCE}_{\mathrm{R}} \cdot \mathrm{SRA}$

\section{Introduction}

The new Ahmad Yani International Airport, Semarang Indonesia was first operated on June 6 2018. The position of the new airport is close to the old airport and moved to the north side of the old airport area. The main objective of the development of the airport is for increasing the passengers demand capacity per year. The new airport uses the same runway with the previous one. The major improvement is the position of airport terminal is moved from the south-part to the north-part of runway and the terminal area is increased from 6708 to $58,652 \mathrm{~m}^{2}$. The airport is located in the north-part of the city and located at the coastal area. The airport was first operated one year after the ISHM-2017 released. Based on the ISHM-2017 the airport location is closed to the new seismic source shallow crustal fault, Semarang Fault. The Semarang fault trace is spreading from the western-part to the center-part of the city. Based on the ISHM-2017 there is another fault trace which is located and spread out at the eastern-part of the city. Figure 1 shows the bird view of the airport area and Fig. 2 shows the airport position toward Semarang fault (with minimum $1 \mathrm{~km}$ distance) and Lasem fault (with minimum $5 \mathrm{~km}$ distance).

Due to the position of the airport against two closest seismic sources, the earthquake scenarios should be taken into consideration for evaluating the capabilities of the infrastructures within the airport area in resisting earthquake waves. A comprehensive investigation should be performed not only to all buildings and

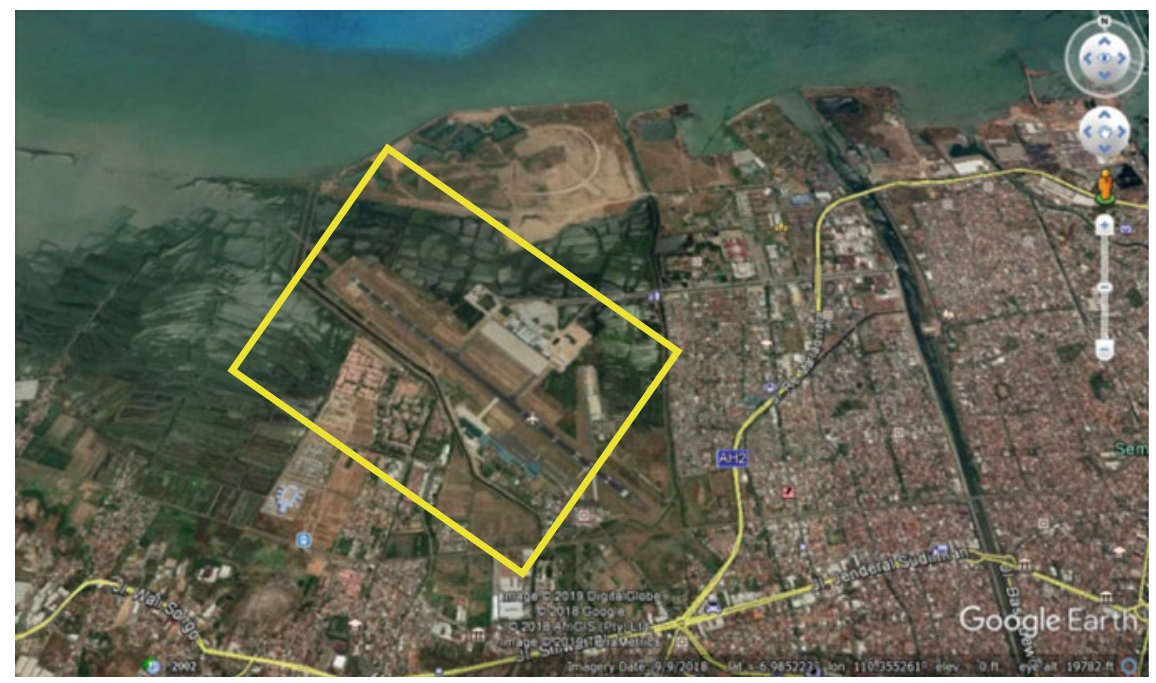

Fig. 1 Bird view Ahmad Yani International Airport 


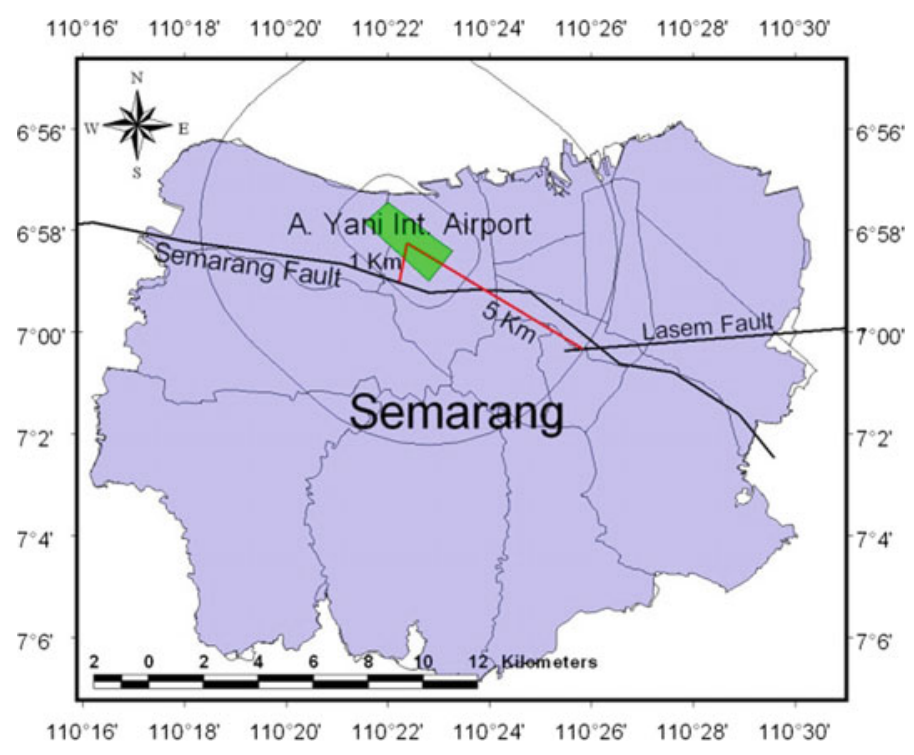

Fig. 2 Position of airport toward two closest seismic sources

facilities within the airport area but also for the seismic mechanisms that might happen to all seismic sources. This paper express one aspect of seismic mitigation related with the possibilities of seismic forces that could be changed to all buildings within the airport. The seismic forces used for building evaluation is developed based on the new ISHM-2017 data and then compared to the previous seismic forces design developed using SNI 1726:2012 [15] and SRA caused by shallow crustal fault earthquake scenario.

Based on the SNI 1726:2012 [15] the seismic forces that can be applied to the buildings is design spectral acceleration (DSA). By using the DSA model of seismic forces, the strength and stability of building structures due to earthquake force scenarios can be predicted.

\section{Methodology}

The development of DSA can be divided into three basic steps. The first step is the Probabilistic and Deterministic Seismic Hazard Analysis (PSHA and DSHA). Following the same method for developing ISHM-2017, the PSHA is developed by conducting $2 \%$ probability of exceedance in 50 years or 2500 years earthquake return periods $[3,9]$. The DSHA is performed based on the maximum earthquake magnitude and the closest distance of earthquake source to site position. The ground motion prediction equations (GMPE) or attenuation functions used for spectral acceleration calculation in PSHA and DSHA are divided into four different 
seismic models such as Shallow Crustal Fault, Shallow Crustal Background, Interface Subduction Megathrust and Benioff Subduction Intraslab. Table 1 shows the GMPE used for spectral acceleration calculation [9]. The weight factor used for spectral acceleration calculation is a factor for obtaining the average value of three different GMPE.

The spectral acceleration of PSHA for each site is calculated using the Total Probability Theorem [11]. The DSHA spectral acceleration is calculated using the same GMPE and the maximum magnitude used for the calculation is adopted based on the research conducted by National Center for Earthquake Studies [13]. Figure 3 shows $0.2 \mathrm{~s}$ and Fig. 4 shows $1 \mathrm{~s}$ uniform hazard curves developed using PSHA at $\left(110.4^{\circ},-7^{\circ}\right)$ [13]. Table 2 shows PSHA with $2 \%$ probability of exceedance in 50 years at 4 (four) different points surrounding the airport position. Table 3 shows DSHA calculated at the same four points.

The next seismic hazard analysis is conducted by combining the PSHA and DSHA for obtaining the Most Considered Earthquake (MCE). The MCE is performed by conducting Risk Targeted Ground Motion (RTGM) analysis of PSHA that can produce $1 \%$ probability of building collapse in 50 years and combine the RTGM analysis result with 84th percentile of DSHA. The RTGM analysis is performed following the same method described by Luco et al. [10], Sengara et al. [14] and ASCE/SEI 7-16 [2] by modifying logarithmic standard deviation $(\beta)$ equal to 0.65 and adjusting direction factor 1.1 and 1.3 for long and short period spectral hazard. The combination analysis of RTGM and DSHA will produce $M_{C} E_{R} S_{S}$ (short period) and $S_{1}$ (long period) spectral acceleration. Table 4 shows $M C E_{R} S_{S}$ and $S_{1}$ calculated at 4 points surrounding Ahmad Yani International Airport.

Two spectral acceleration $M \mathrm{MCE}_{\mathrm{R}} \mathrm{S}_{\mathrm{S}}$ and $\mathrm{S}_{1}$ are then used for developing the final steps such as surface spectral accelerations $\left(S_{M S}\right.$ and $\left.S_{M 1}\right)$ and DSA $\left(S_{D S}\right.$ and $\left.S_{D 1}\right)$. Based on SNI 1726:2012 [15] and ASCE/SEI 7-16 [2] the DSA $\left(S_{\mathrm{DS}}\right.$ and $\left.\mathrm{S}_{\mathrm{D} 1}\right)$ is $2 / 3$ (two-third) of the surface spectral acceleration $S_{M S}$ and $S_{M 1}$. The surface

Table 1 Ground motion prediction equation

\begin{tabular}{|c|c|c|c|}
\hline No & Seismic source model & GMPE & Weight factor \\
\hline \multirow[t]{3}{*}{1} & \multirow[t]{3}{*}{ Shallow crustal fault } & Boore and Atkinson [5] & 0.333 \\
\hline & & Campbell and Bozorgnia [6] & 0.333 \\
\hline & & Chiou and Youngs [7] & 0.333 \\
\hline \multirow[t]{3}{*}{2} & \multirow{3}{*}{ Shallow background } & Boore and Atkinson [5] & 0.333 \\
\hline & & Campbell and Bozorgnia [6] & 0.333 \\
\hline & & Chiou and Youngs [7] & 0.333 \\
\hline \multirow[t]{3}{*}{3} & \multirow[t]{3}{*}{ Interface subduction megathrust } & Abrahamson et al. [1] & 0.333 \\
\hline & & Zhao et al. [18] & 0.333 \\
\hline & & Atkinson and Boore [4] & 0.333 \\
\hline \multirow[t]{3}{*}{4} & \multirow[t]{3}{*}{ Benioff subduction intraslab } & Youngs et al. [17] & 0.333 \\
\hline & & Atkinson and Boore [4] & 0.333 \\
\hline & & Atkinson and Boore [4] & 0.333 \\
\hline
\end{tabular}




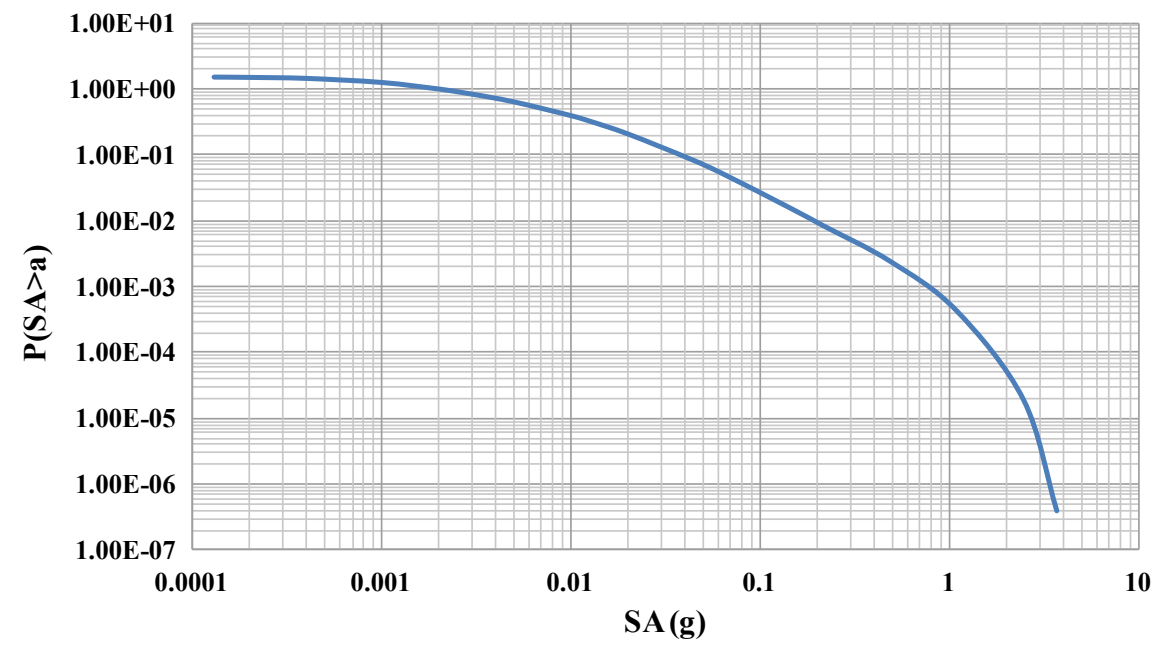

Fig. 3 Uniform hazard curve $0.2 \mathrm{~s}$ calculated at $\left(110.4^{\circ},-7^{\circ}\right)$ [13]

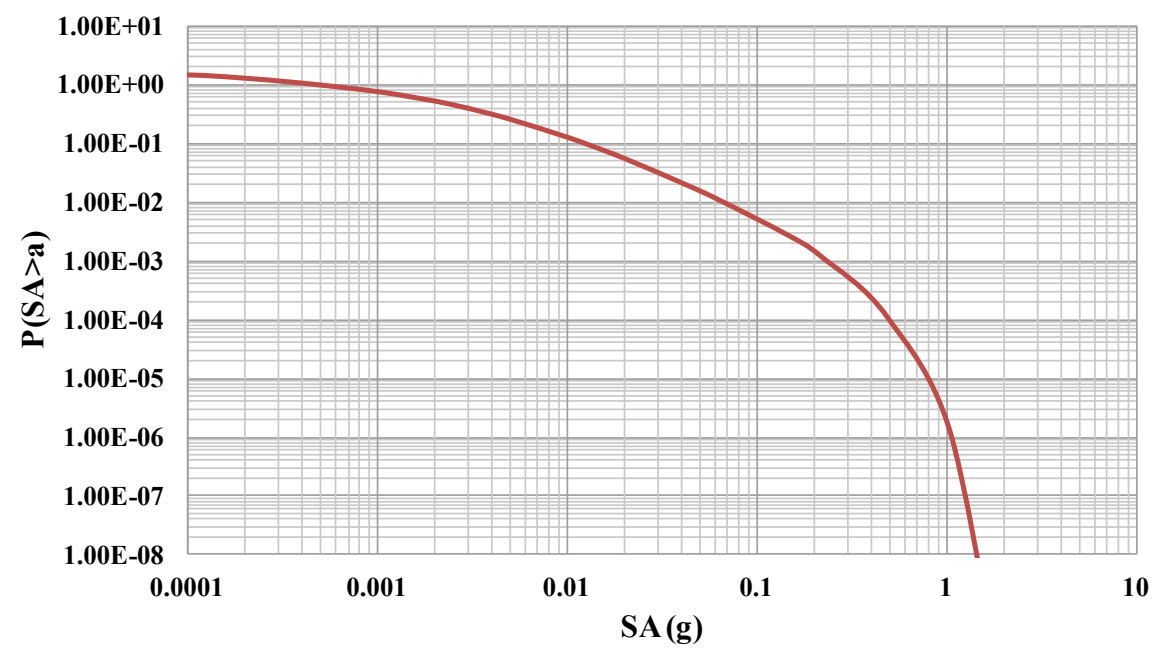

Fig. 4 Uniform hazard curve $1 \mathrm{~s}$ calculated at $\left(110.4^{\circ},-7^{\circ}\right)[13]$

spectral acceleration $\mathrm{S}_{\mathrm{MS}}$ and $\mathrm{S}_{\mathrm{M} 1}$ at the airport area are calculated using two site factors $F a$ (for $S_{S}$ ) and $F v$ (for $S_{1}$ ). The value of $F a$ and $F v$ are calculated based on the site class soil $[2,15]$. This research used two types of site factors such as site factor used by SNI 1726:2012 [15] and site factors announced by Stewart and Seyhan [16] as a modified site factor for SE class used by ASCE/SEI 7-16 [2]. These two models of site factor are used for developing $S_{M S}$ and $S_{M 1}$ surface spectral acceleration. 
Table 2 PSHA spectral acceleration calculated for $2 \%$ probability of occurrence in 50 years [13]

\begin{tabular}{l|l|l|l|l}
\hline No & Longitude $\left(^{\circ}\right)$ & Latitude $\left(^{\circ}\right)$ & \multicolumn{3}{|l}{ PSHA } \\
\cline { 4 - 5 } & & & $0.2 \mathrm{~s}(\mathrm{~g})$ & $1 \mathrm{~s}(\mathrm{~g})$ \\
\hline 1 & 110.3 & -6.9 & 0.73536 & 0.34395 \\
\hline 2 & 110.3 & -7.0 & 1.01976 & 0.43813 \\
\hline 3 & 110.4 & -6.9 & 0.70469 & 0.33458 \\
\hline 4 & 110.4 & -7.0 & 0.99770 & 0.43311 \\
\hline
\end{tabular}

Table 3 DSHA 2017 [13]

\begin{tabular}{l|l|l|l|l}
\hline No & Longitude $\left(^{\circ}\right)$ & Latitude $\left(^{\circ}\right)$ & \multicolumn{2}{|l}{ DSHA } \\
\cline { 3 - 5 } & & & $0.2 \mathrm{~s}(\mathrm{~g})$ & $1 \mathrm{~s}(\mathrm{~g})$ \\
\hline 1 & 110.3 & -6.9 & 0.7503 & 0.1857 \\
\hline 2 & 110.3 & -7.0 & 1.4334 & 0.3638 \\
\hline 3 & 110.4 & -6.9 & 0.6405 & 0.1524 \\
\hline 4 & 110.4 & -7.0 & 1.4494 & 0.3873 \\
\hline
\end{tabular}

Table $4 \mathrm{MCE}_{\mathrm{R}} \mathrm{S}_{\mathrm{S}}$ and $\mathrm{S}_{1}$ at 4 points close to the Airport position

\begin{tabular}{l|l|l|l|l}
\hline No & Longitude $\left(^{\circ}\right)$ & Latitude $\left(^{\circ}\right)$ & \multicolumn{3}{|l}{$\mathrm{MCE}_{\mathrm{R}}$} \\
\cline { 4 - 5 } & & & $\mathrm{S}_{\mathrm{S}}(\mathrm{g})$ & $\mathrm{S}_{1}(\mathrm{~g})$ \\
\hline 1 & 110.3 & -6.9 & 0.73536 & 0.34395 \\
\hline 2 & 110.3 & -7.0 & 1.01976 & 0.43813 \\
\hline 3 & 110.4 & -6.9 & 0.70469 & 0.33458 \\
\hline 4 & 110.4 & -7.0 & 0.99770 & 0.43311 \\
\hline
\end{tabular}

The DSA developed based on the new SHMI-2017 and ASCE/SEI 7-16 [2] is then compared to the previous DSA at the same location calculated using SNI 1726:2012 [15]. If the new DSA is equal or almost equal or less than the DSA develop from SNI 1726:2012 [15], the buildings and infrastructures located at the airport area are predicted have the capability in resisting earthquake caused by all seismic sourced introduced in SHMI-2017.

The DSA calculated using two different seismic codes, SNI 1726:2012 [15] and modified ASCE/SEI 7-16 [2], are then compared to the surface spectral acceleration calculated using Site Response Analysis (SRA). The SRA was performed using geotechnical investigation data and Microtremor investigation data. The purpose of the Microtremor investigation is for predicting the bedrock elevation [8]. Using this bedrock elevation and soil dynamic data, the SRA is then performed based on Kelvin-Voigt equivalent linear model. The predicted bedrock elevation investigation was performed by Partono et al. [12]. Surface spectral acceleration was developed using acceleration time history produced by San Simeon earthquake (reverse mechanism) data having a magnitude of $6.52 \mathrm{Mw}$ and epicenter distance $5.07 \mathrm{~km}$. The acceleration time histories used in SRA was collected from Pacific Earthquake Engineering Research (PEER) database. The magnitude value is 
adjusted based on the SHMI-2017 information for Semarang fault. For seismic hazard analysis the maximum magnitude of Semarang fault model is adjusted to 6.5 Mw.

\section{Result and Discussions}

Ahmad Yani International Airport is located closed to two seismic sources Semarang and Lasem faults. As mention in Fig. 2 the minimum distance to Semarang fault trace is approximately less than $1 \mathrm{~km}$ and the minimum distance to Lasem fault trace is less than $5 \mathrm{~km}$. To evaluate the effect of those two seismic sources toward the airport buildings it is important to check the distribution of PGA (Peak Ground Acceleration), short period (0.2 s) and long period (1 s) spectral acceleration calculated using PSHA and DSHA. Figure 5 shows the PGA map, Fig. 6 shows the $0.2 \mathrm{~s}$ spectral acceleration map and Fig. 7 shows the distribution of $1 \mathrm{~s}$ spectral acceleration map developed using PSHA (PUSGEN, 2017) for the whole area of the city. The development of three seismic hazard maps is conducted using $2 \%$ probability of exceedance in 50 years or 2500 years return period earthquake. As it can seen in those three figures the maximum spectral acceleration is distributed close to the fault trace. The PGA, $0.2 \mathrm{~s}$ and $1 \mathrm{~s}$ spectral accelerations are in between $0.19-0.21 \mathrm{~g}, 0.8-1.1 \mathrm{~g}$ and $0.37-0.44 \mathrm{~g}$ respectively ("g" is a gravitational acceleration $=9.81 \mathrm{~m} / \mathrm{s}^{2}$ ).

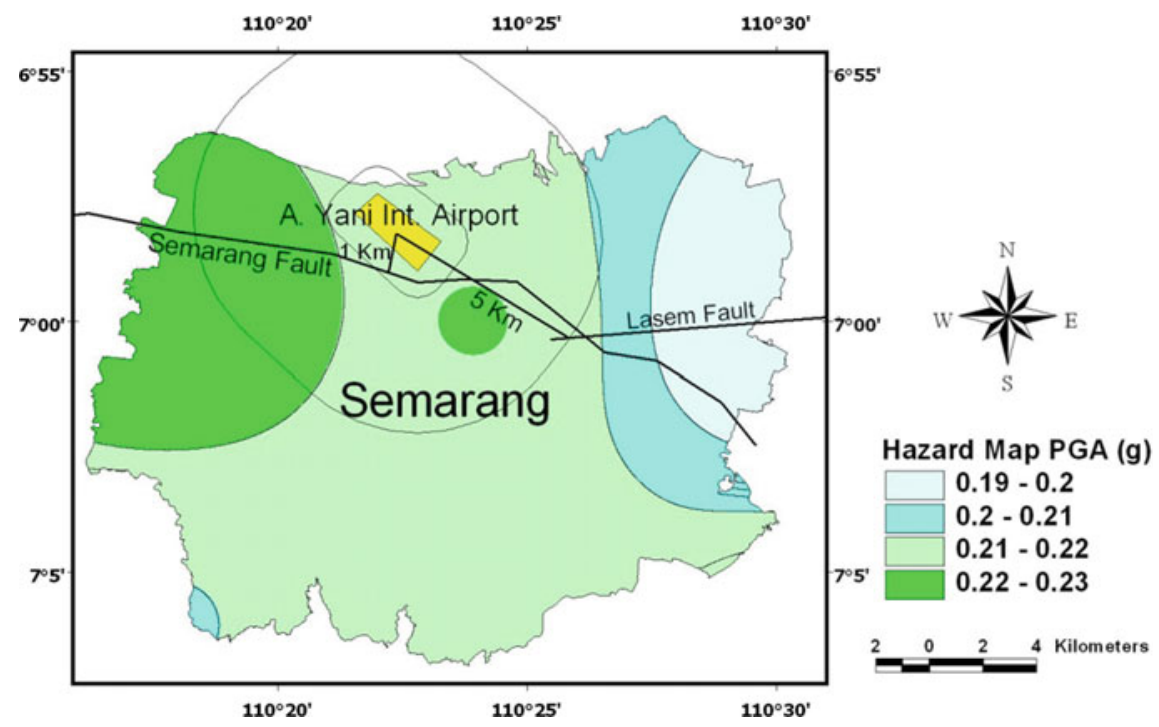

Fig. 5 PGA map with $2 \%$ probability of occurrence in 50 years [13] 


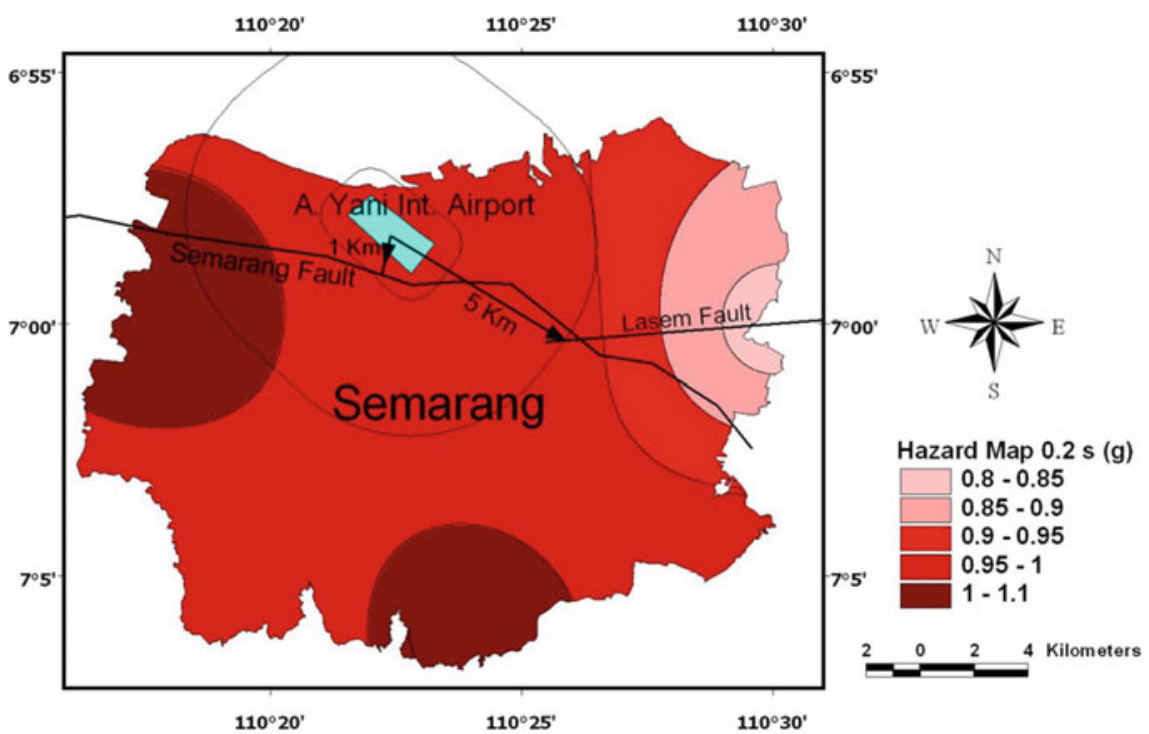

Fig. 6 Hazard map $0.2 \mathrm{~s}$ with $2 \%$ probability of occurrence in 50 years [13]

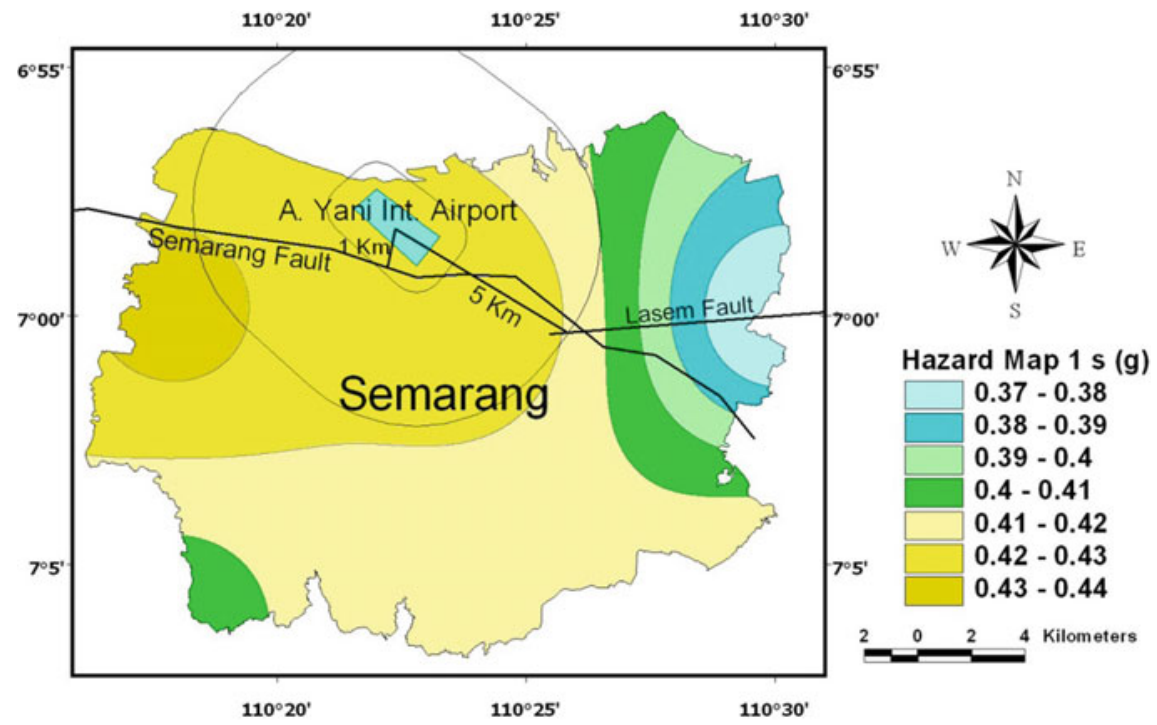

Fig. 7 Hazard map $1 \mathrm{~s}$ with $2 \%$ probability of occurrence in 50 years [13] 
The evaluation of airport area toward seismic acceleration is also conducted using DSHA. Figure 8 shows the distribution of PGA caused by subduction earthquake having a maximum magnitude of $8.5 \mathrm{Mw}$. Figure 9 shows the distribution of PGA caused by Semarang and Lasem faults having a maximum magnitude of $6.6 \mathrm{Mw}$ [13]. It can be seen in Figs. 8 and 9 the PGA values causes by subduction earthquake with magnitude $8.5 \mathrm{Mw}$ is less than $0.1 \mathrm{~g}$. However the PGA values caused by fault earthquake are greater than subduction earthquake.

The $\mathrm{MCE}_{\mathrm{R}} \mathrm{S}_{\mathrm{S}}$ and $\mathrm{S}_{1}$ spectral accelerations calculation were developed using the combination of PSHA (for producing RTGM spectral acceleration with 1\% probability of collapses in 50 years) and $84^{\text {th }}$ percentile of DSHA. The RTGM calculation was performed by conducting the same method proposed by Luco et al. [10] and ASCE/SEI 7-16 [2] and applying different logarithmic standard deviation value " $\beta$ " equal to 0.65 and adjusting 1.1 and 1.3 direction factors for short and long period spectral accelerations. Table 4 shows the $\mathrm{MCE}_{\mathrm{R}} \mathrm{S}_{\mathrm{S}}$ and $\mathrm{S}_{1}$ data calculated at four different points located closed to airport position. The reason why it should be calculated at four points due to the position of the airport coordinate is not equal toward national seismic hazard maps coordinate data developed by ISHM-2017. The $\mathrm{MCE}_{\mathrm{R}} \mathrm{S}_{\mathrm{S}}$ and $\mathrm{S}_{1}$ were calculated at $\left(110.35^{\circ},-6.95^{\circ}\right)$ airport coordinate by conducting weight factor of four points. The weight factor is developed based on the site distance toward four points. The $\mathrm{MCE}_{\mathrm{R}} \mathrm{S}_{\mathrm{S}}$ and $\mathrm{S}_{1}$ result obtained at this point is 0.7965 and $0.3512 \mathrm{~g}$ respectively. Due to the coordinate of airport position, the $\mathrm{MCE}_{\mathrm{R}} \mathrm{S}_{\mathrm{S}}$ and $\mathrm{S}_{1}$ should be verified based on the closest four pairs $\mathrm{S}_{\mathrm{S}}$ and $\mathrm{S}_{1}$ values as mention in Table 4.

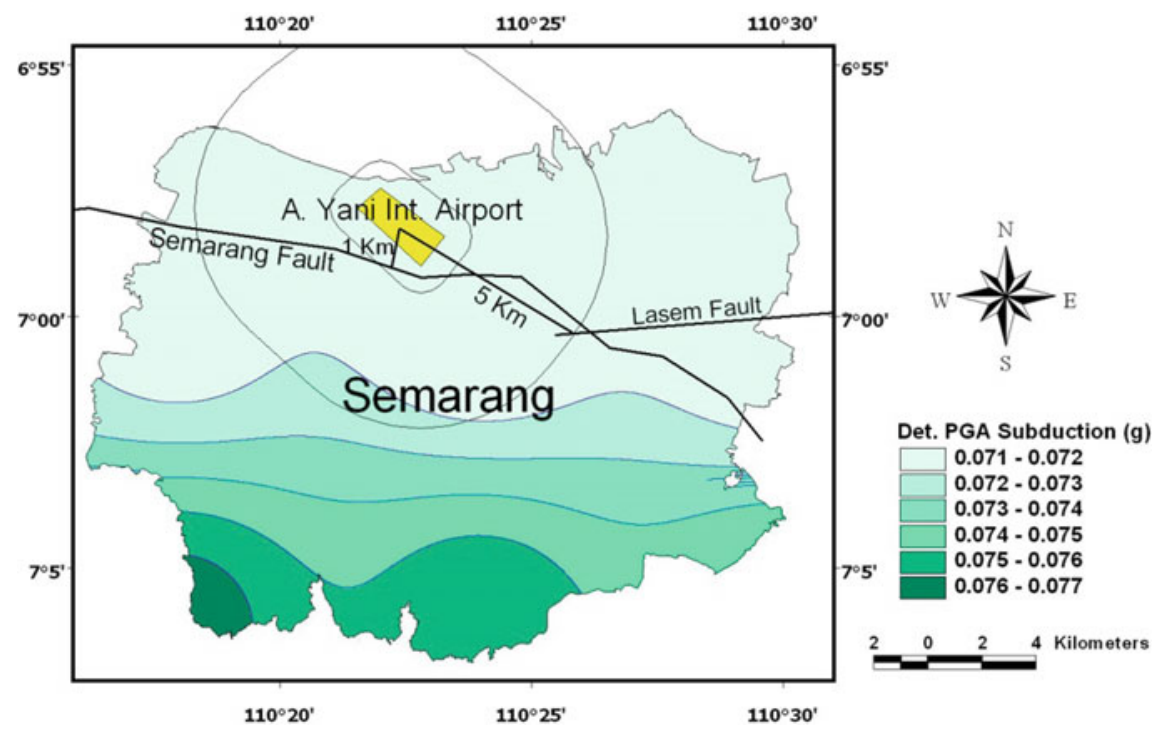

Fig. 8 Deterministic PGA map caused by subduction earthquake 


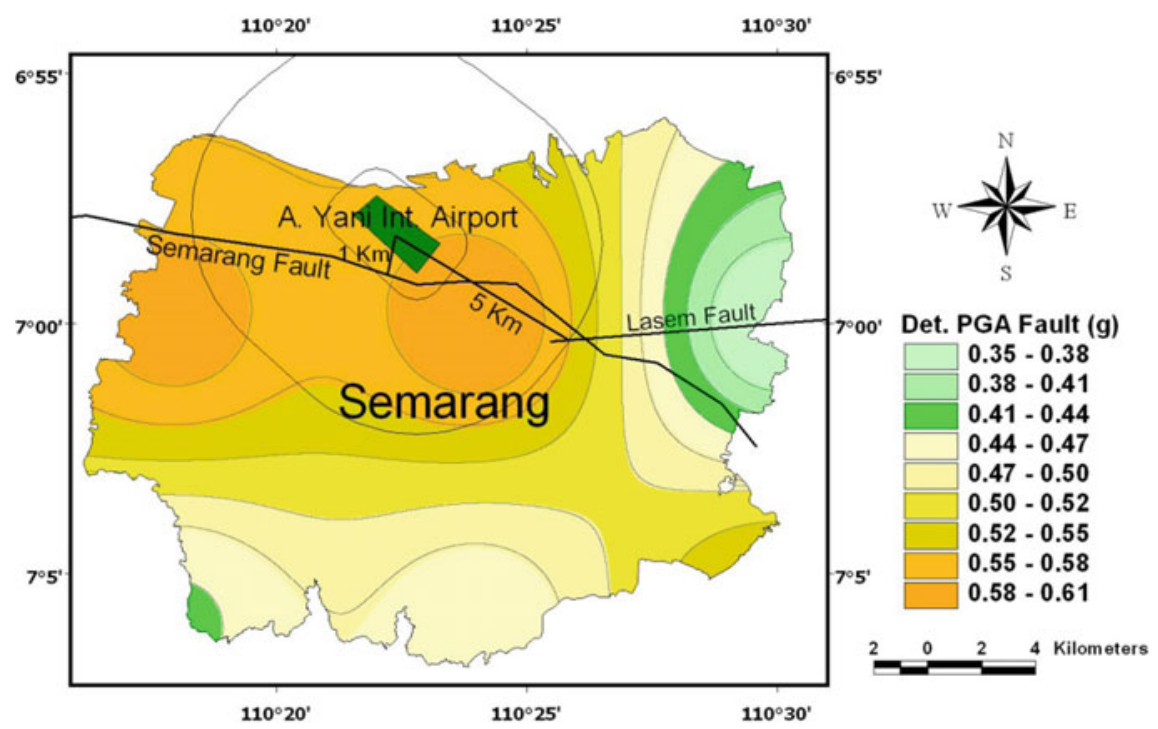

Fig. 9 Deterministic PGA map caused by shallow crustal fault earthquake

The DSA at the airport is developed by first conducting the evaluation of boring investigation result. Nine boring investigations were conducted on site with maximum $52 \mathrm{~m}$ depth. Standard Penetration Test (N-SPT) investigation was conducted at each boring position with $2 \mathrm{~m}$ interval. Figure 10 shows the N-SPT profile result conducted at 9 boring positions. Based on the result of nine boring investigations the average of N-SPT value at top $30 \mathrm{~m}$ soil deposit $(\mathrm{N}-30)$ is 2.67 or less than 15 . Based on SNI 1726:2012 [15] the airport buildings and infrastructures are located in SE (soft soil) class. As it can seen in Fig. 10 the N-SPT values at $0-10 \mathrm{~m}$ depth is in between 0 and 2. The minimum to maximum values of N-SPT in between 10 and $20 \mathrm{~m}$ depth is 2 to 18 and for $20-30 \mathrm{~m}$ depth is in between 8 and 30 .

Two site factors $\mathrm{Fa}$ and $\mathrm{Fv}$ are required for developing DSA at the airport position. Two different methods are conducted at this location for obtaining Fa and Fv. First by using the same values used by SNI 1726:2012 [15] and the second is by using the values proposed by Stewart and Seyhan [16] (modified ASCE/SEI 7-16 [2]). Table 5 shows list of Fa and Fv site factors used in SNI 1726:2012 [15] and Table 6 shows list of Fa and Fv site factors developed by Stewart and Seyhan [16] (modified ASCE/SEI 7-16 [2]) for site class SE (soft soil). Table 7 shows two difference results of site factor $\mathrm{Fa}$ and Fv calculated using the same MCER $\mathrm{S}_{\mathrm{S}}$ and S1 values. Following the same method described by SNI 1726:2012 [15] and ASCE/SEI 7-16 [2] the surface spectral acceleration $S_{M S}$ and $S_{M 1}$ can be calculated by multiplying the site factor Fa toward $S_{S}$ and FV toward $S_{1}$. Table 8 shows the $\mathrm{S}_{\mathrm{MS}}$ and $\mathrm{S}_{\mathrm{M} 1}$ calculated using two difference site factors, such as SNI 1726:2012 [15] and Stewart and Seyhan [16]. The $S_{M S}$ value calculated using Stewart and 


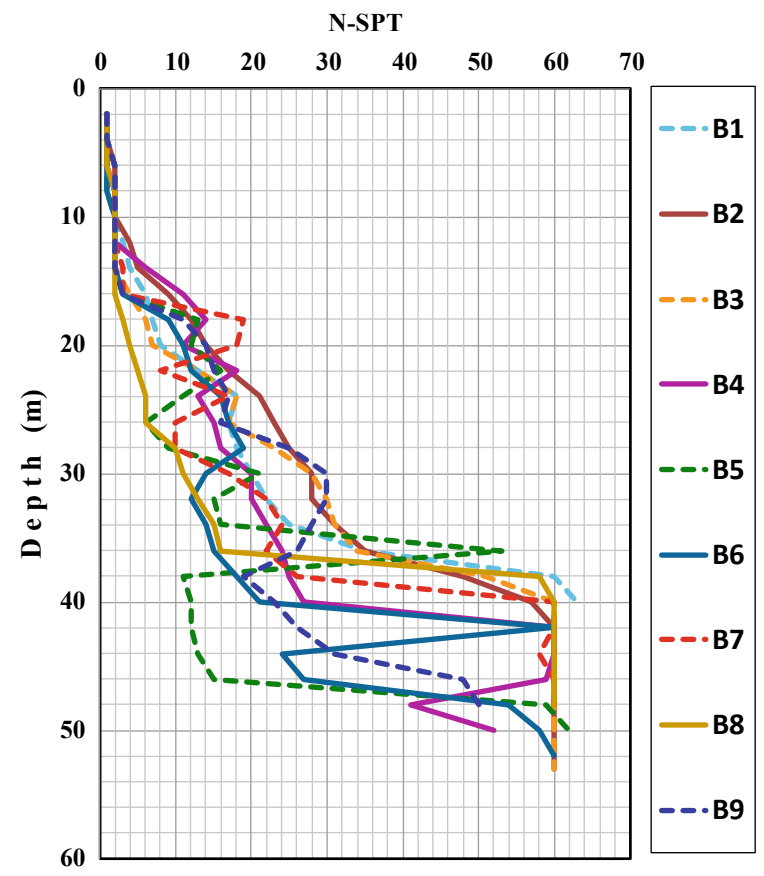

Fig. 10 N-SPT profiles developed from 9 position boring investigations

Table 5 Fa and Fv used by SNI 1726:2012 [15] for site class SE

\begin{tabular}{l|l|l|l|l|l}
\hline Site factor & \multicolumn{5}{|l}{ Site class SE } \\
\hline \multirow{2}{*}{$\mathrm{Fa}$} & $\mathrm{SS} \leq 0.25$ & $\mathrm{SS}=0.5$ & $\mathrm{SS}=0.75$ & $\mathrm{SS}=1$ & $\mathrm{SS} \geq 1.25$ \\
\cline { 2 - 6 } & 2.5 & 1.7 & 1.2 & 0.9 & 0.9 \\
\hline \multirow{2}{*}{$\mathrm{Fv}$} & $\mathrm{S} 1 \leq 0.1$ & $\mathrm{~S} 1=0.2$ & $\mathrm{~S} 1=0.3$ & $\mathrm{~S} 1=0.4$ & $\mathrm{~S} 1 \geq 0.5$ \\
\cline { 2 - 6 } & 3.5 & 3.2 & 2.8 & 2.4 & 2.4 \\
\hline
\end{tabular}

Table 6 Fa and Fv developed by Stewart and Seyhan [16] for site class SE

\begin{tabular}{l|l|l|l|l|l|l}
\hline Site factor & \multicolumn{4}{|l}{ Site class SE } & \\
\hline $\mathrm{Fa}$ & $\mathrm{SS} \leq 0.25$ & $\mathrm{SS}=0.5$ & $\mathrm{SS}=0.75$ & $\mathrm{SS}=1$ & $\mathrm{SS}=1.25$ & $\mathrm{SS} \geq 1.5$ \\
\cline { 2 - 7 } & 2.4 & 1.7 & 1.3 & 1.1 & 0.9 & 0.8 \\
\hline \multirow{2}{*}{$\mathrm{Fv}$} & $\mathrm{S} 1 \leq 0.1$ & $\mathrm{~S} 1=0.2$ & $\mathrm{~S} 1=0.3$ & $\mathrm{~S} 1=0.4$ & $\mathrm{~S} 1=0.5$ & $\mathrm{~S} 1 \geq 0.6$ \\
\cline { 2 - 7 } & 4.2 & 3.3 & 2.8 & 2.4 & 2.2 & 2.0 \\
\hline
\end{tabular}


Table 7 Fa and Fv calculated using two different methods

\begin{tabular}{l|l|l}
\hline \multirow{2}{*}{ Method } & $\mathrm{S}_{\mathrm{S}}=0.7965 \mathrm{~g}$ & $\mathrm{~S}_{1}=0.3512 \mathrm{~g}$ \\
\cline { 2 - 3 } & $\mathrm{Fa}$ & $\mathrm{Fv}$ \\
\hline SNI 1726:2012 [15] & 1.144 & 2.596 \\
\hline Stewart and Seyhan [16] & 1.295 & 2.595 \\
\hline
\end{tabular}

Table 8 The $\mathrm{S}_{\mathrm{MS}}$ and $\mathrm{S}_{\mathrm{M} 1}$ calculated using two different site factors

\begin{tabular}{l|l|l}
\hline Method & $\mathrm{S}_{\mathrm{MS}}(\mathrm{g})$ & $\mathrm{S}_{\mathrm{M} 1}(\mathrm{~g})$ \\
\hline SNI 1726:2012 [15] & 0.9105 & 0.912 \\
\hline Stewart and Seyhan [16] & 1.0305 & 0.912 \\
\hline
\end{tabular}

Seyhan [16] (Table 6) is greater than the $S_{M S}$ calculated at the same location using SNI 1726:2012 [15] (Table 5).

Based on SNI 1726:2012 [15] and modified ASCE/SEI 7-16 [2] all buildings should be design using DSA as a model of seismic force. The existing buildings which are already designed using previous DSA [15] shall be evaluated and compared to the new DSA (modified ASCE/SEI 7-16 [2] code). The evaluation should be performed for existing building due to the update data of earthquake records. As already mention before that the existing buildings and infrastructures within the airport area were designed based on SNI 1726:2012 [15]. The new ISHM-2017 has already released in 2017. The DSA developed based on SNI 1726:2012 [15] should be compared to the DSA calculated based on ISHM-2017. Table 9 shows the $S_{D S}$ and $S_{D 1}$ values calculated at the airport position $\left(110.35^{\circ}\right.$, $-6.95^{\circ}$ ) based on SNI 1726:2012 [15] and modified ASCE/SEI 7-16 [2]. As it can seen in Table 8, the $S_{M S}$ and $S_{M 1}$ values for SNI 1726:2012 [15] are different compared to Table 9. The $S_{M S}$ and $S_{M 1}$ in Table 8 are calculated using $S_{S}$ $(0.7965 \mathrm{~g})$ and $\mathrm{S}_{1}(0.3512 \mathrm{~g})$ as already mentioned in Table 7 . However the $\mathrm{S}_{\mathrm{MS}}$ and $S_{M 1}$ [15] in Table 9 were developed for existing airport design. Figure 11 shows two difference curves of DSA for site class SE calculated using SNI 1726:2012 [15] (SE-2012) and modified ASCE/SEI 7-16 [2] (SE-2019). As it can be seen in this figure there is no significant improvement of DSA at the airport site.

The DSA developed using two different codes, SNI 1726:2012 [15] and modified ASCE/SEI 7-16 [2] are then evaluated toward SRA. The purposed of SRA is to evaluate the possibility of earthquake force caused by specific earthquake scenario. The SRA was performed by conducting earthquake scenario having a magnitude of $6.52 \mathrm{Mw}$ and epicenter distance $5.07 \mathrm{~km}$ which represents Semarang fault earthquake scenario. The acceleration time histories (North-South/NS and

Table 9 The $S_{D S}$ and $S_{D 1}$ calculated using two different seismic codes

\begin{tabular}{l|l|l|l|l}
\hline Method & $\mathrm{S}_{\mathrm{MS}}(\mathrm{g})$ & $\mathrm{S}_{\mathrm{M} 1}(\mathrm{~g})$ & $\mathrm{S}_{\mathrm{DS}}(\mathrm{g})$ & $\mathrm{S}_{\mathrm{D} 1}(\mathrm{~g})$ \\
\hline SNI 1726:2012 [15] & 0.909 & 0.808 & 0.606 & 0.539 \\
\hline Modified ASCE/SEI 7-16 [2] & 1.0305 & 0.912 & 0.687 & 0.608 \\
\hline
\end{tabular}




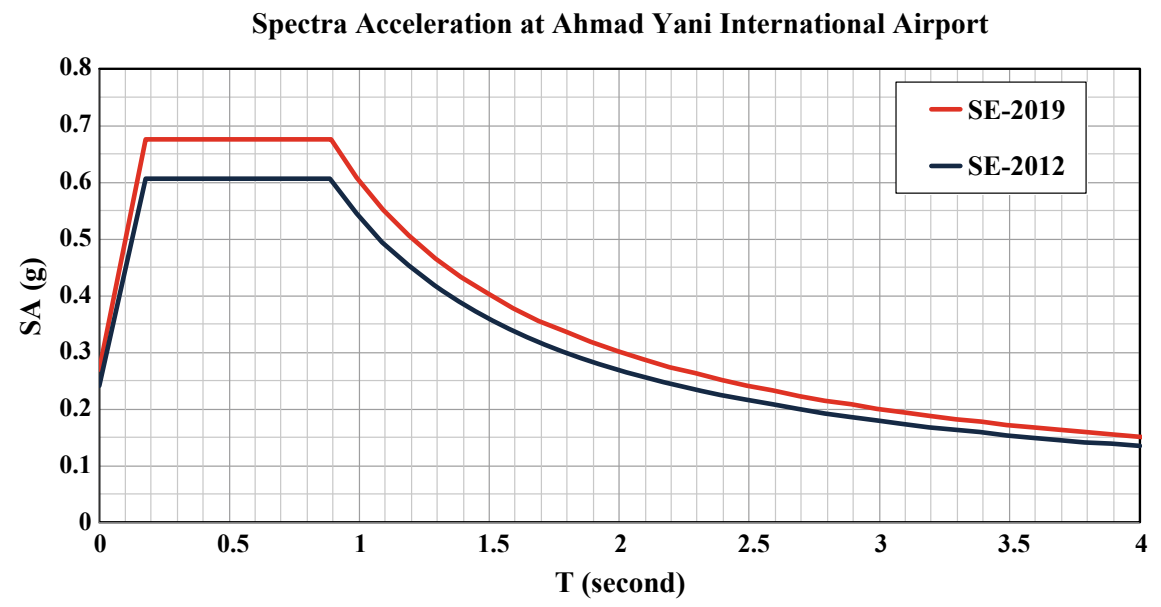

Fig. 11 The difference of DSA for Ahmad Yani Airport based on SNI 1726:2012 [15] (SE-2012) and modified ASCE/SEI 7-16 [2] (SE-2019)

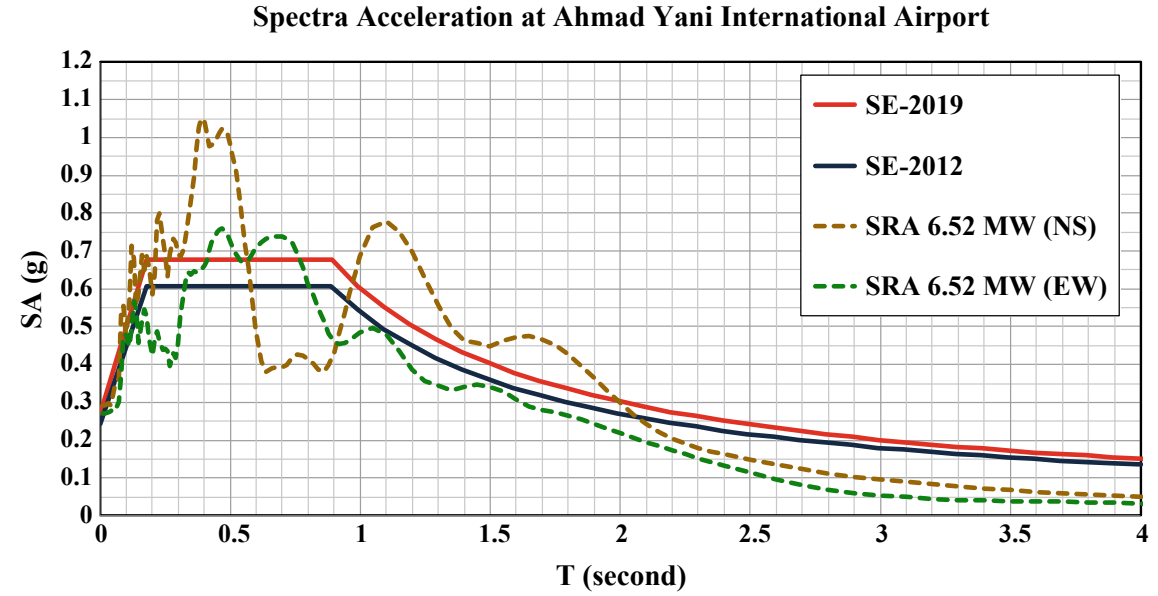

Fig. 12 Comparative SRA spectral acceleration toward two DSA for Ahmad Yani Airport

East-West/EW) used for SRA are collected from San Simeon earthquake. The San Simeon earthquake was conducted for SRA calculation due to the difficulties for collecting ground motion data of reverse mechanism source earthquakes. As it can seen in Fig. 12 the surface spectral acceleration developed by using two directions acceleration time histories (NS and EW) earthquake scenario are almost equal compared to the DSA developed based on SNI 1726:2012 [15] (SE-2012) and modified ASCE/SEI 7-16 [2] (SE-2019). Based on the DSA and SRA analysis as can be seen in Fig. 12 the buildings and infrastructures within the airport area 
which already designed using SNI 1726:2012 [15] are predicted have the capabilities in resisting earthquake scenarios due to Semarang and Lasem earthquake having a magnitude $6.5 \mathrm{Mw}$ and minimum $5 \mathrm{~km}$ epicenter distance to the airport position.

\section{Conclusions}

Research on the evaluation of the new Ahmad Yani International Airport in Semarang, Indonesia against predicted earthquake force has already performed. The proposed of this research is to evaluate the capability of structures in resisting predicted earthquakes with probability of exceedance $2 \%$ in 50 years. The evaluation was performed due to the position of the airport area is less than $1 \mathrm{~km}$ to the new developed Semarang Fault trace and less than $5 \mathrm{~km}$ to Lasem Fault trace. The evaluation is restricted only on the design earthquake force criterion in terms of DSA calculation results.

DSA is a model of earthquake force usually used for seismic resistance design for buildings and non buildings. The new DSA is developed based on modified ASCE/SEI 7-16 [2] by modifying the method of $\mathrm{MCE}_{\mathrm{R}} \mathrm{S}_{\mathrm{S}}$ and $\mathrm{S}_{1}$ calculation. The $\mathrm{MCE}_{\mathrm{R}}$ analysis is performed by combining RTGM with $1 \%$ probability of collapses in 50 years and 84th percentile of DSHA. The RTGM analysis is performed using PSHA result analysis by applying logarithmic standard deviation value " $\beta$ " equal to 0.65 and direction factor 1.1 and 1.3 for short and long period spectral accelerations respectively.

The second modification for DSA is conducted by using two site factors Fa and Fv for developing surface spectral acceleration $\left(S_{M S}\right.$ and $\left.S_{M 1}\right)$. The two Fa and Fv site factor values are applied in this research by conducting the same values proposed by Stewart and Seyhan [16].

The development of DSA is also conducted using 9 boring investigations. The purpose of this investigation is to obtain the information of site soil class of the airport area. The standard penetration test is also performed with interval $2 \mathrm{~m}$ depths for obtaining N-SPT and average N-SPT values at the top 30 meters soil layers at each boring position. Based on the average N-SPT (at top $30 \mathrm{~m}$ soil layer) values calculated at 9 boring positions the airport area is located at soft soil (SE) class.

Based on the site data obtained at the airport area, the DSA is then calculated and compared with the DSA of SNI 1726:2012 [15]. The new DSA (calculated using modified ASCE/SEI 7-16 [2]) is bigger compared to the previous DSA [15]. However there is no significant improvement of the new DSA compared to DSA [15].

The DSA developed based on the modified ASCE/SEI 7-16 [2] and SNI 1726:2012 [15] are then compared to the surface spectral acceleration calculated using site response analysis (SRA). The SRA was performed by conducting a scenario earthquake having a magnitude of $6.52 \mathrm{Mw}$ and $5.07 \mathrm{~km}$ epicenter 
distance which represents shallow crustal fault scenario (Semarang and Lasem fault earthquake). The spectral acceleration developed by three different methods (ASCE 1726:2012, modified ASCE/SEI 7-16 [2] and SRA) are almost equal and have no significant improvements. Based on the information related with the DSA and SRA analysis, the buildings or infrastructures built in the airport area is predicted save enough for resisting the predicted earthquake caused by Semarang and Lasem fault having a magnitude of $6.5 \mathrm{Mw}$ and epicenter distance minimum $5 \mathrm{~km}$.

Acknowledgements This research was financially supported by The Faculty of Engineering, Diponegoro University, Indonesia trough Strategic Research Grant 2019. The Author also would like to thank to the Ministry of Public Works and Human Settlements Indonesia and National Center for Earthquake Studies (PUSGEN) for providing data and technical supports during the development of this research. The Author would like to express the deepest appreciation to Jaya Contractor for providing geotechnical data and geotechnical investigation.

\section{References}

1. Abrahamson NA, Gregor N, Addo K (2016) BC hydro ground motion prediction equation for subduction earthquakes. Earthq Spectra 32(1):23-44

2. ASCE/SEI 7-16 (2017) Minimum design loads and associated criteria for buildings and other structures. American Society of Civil Engineers

3. Asrurifak M, Irsyam M, Budiono B, Triyoso W, Djazilus H (2010) Development of spectral hazard map for Indonesia with a return period of 2500 years using probabilistic method. Civ Eng Dimension 12(1):52-62

4. Atkinson GM, Boore DM (2003) Empirical ground-motion relations for subduction-zones earthquakes and their application to Cascadia and other regions. Bull Seismol Soc Am 93 (4): $1702-1729$

5. Boore DM, Atkinson GM (2008) Ground motion prediction equations for the average horizontal component of PGA and PGV and 5\% damped PSA at spectral periods between $0.01 \mathrm{~s}$ to $10 \mathrm{~s}$. Earthq Spectra 24(1):99-138

6. Campbell KW, Bozorgnia Y (2008) NGA ground motion model for the geometric mean horizontal component of PGA, PGV and PGD and 5\% damped linear elastic response for periods ranging from 0.01 to $10 \mathrm{~s}$. Earthq Spectra 24(1):139-171

7. Chiou BSJ, Young RR (2008) NGA model for average horizontal component of peak ground motion and response spectra. In: PEER 2008/2009, Pacific earthquake engineering research center, College of Engineering, University of California, Berkeley, pp 1-94

8. Gosar A (2017) Study on the applicability of the microtremor HVSR method to support seismic microzonation in the town of Idrija (West Slovenia). Nat Hazard Earth Syst Sci 17:925-937

9. Irsyam M, Hendriyawan NDH, Daryono MR, Widiyantoro S, Asrurifak M, Meilano I, Triyoso W, Hidayati S, Rudiyanto A (2017) Development of new seismic hazard maps of Indonesian. In: Proceedings of the 19th international conference on soil mechanics and geotechnical engineering, Seoul, pp 1525-1528

10. Luco N, Ellingwood BR, Hamburger RO, Hooper JD, Kinball JK, Kircher CA (2007) Risk targeted versus current seismic design maps for the coterminous United States. In: Structural engineers association of California 2007 convention proceedings, pp 163-175

11. McGuire RK (1995) Probabilistic seismic hazard analysis and design earthquakes, closing the loop. Bull Seismol Soc Am 85(5):1275-1284 
12. Partono W, Prabandiyani SPR, Irsyam M, Maarif S (2016) Seismic microzonation of semarang Indonesia based on site response analysis using $30 \mathrm{~m}$ soil deposit model. Jurnal Teknologi 78(8-5):31-38

13. Pusat Studi Gempa Nasional (PUSGEN) (2017) Peta Sumber dan Bahaya Gempa Indonesia Tahun 2017. Pusat Litbang Perumahan dan Pemukiman, Kementerian Pekerjaan Umum dan Perumahan Rakyat (National Center for Earthquake Studies. Indonesian Seismic Sources and Seismic Hazard Maps 2017. Center for Research and Development of Housing and Resettlement, Ministry of Public Works and Human Settlements), pp 1-377. ISBN 978-602-5489-01-3

14. Sengara IW, Irsyam M, Sidi ID, Mulia A, Asrurifak M, Hutabarat D (2015) Development of risk-targeted ground motions for Indonesian earthquake resistance building code SNI 1726-2012. In: 12th international conference on applications of statistics and probability in civil engineering, ICASP12, Vancouver, Canada, 12-15 July

15. SNI 1726:2012 (2012) Tata Cara Perencanaan Ketahanan Gempa untuk Struktural Bangunan Gedung dan Non Gedung (Seismic resistance design codes for building and other structures), Jakarta, pp 1-138

16. Stewart JA, Seyhan E (2013) Semi-empirical nonlinear site amplification and its application in NEHRP site factors. Pacific earthquake engineering research center (PEER) Report 2013/13. University of California, Berkelay, Nov 2013

17. Youngs RR, Chiou SJ, Silva WJ, Humphrey JR (1997) Strong ground motion attenuation relationships for subduction zone earthquakes. Seismol Res Lett 68(1):58-73

18. Zhao JX, Irikura K, Zhang J, Fukuzima Y, Sommerville PG, Asano A, Ohno Y, Oouchi T, Takahashi T, Ogawa H (2006) An empirical site-classification method for strong-motion stations in Japan H/V response spectral ratio. Bull Seismol Soc Am 96(3):914-925 